\title{
Gas Cylinder
}

National Cancer Institute

\section{Source}

National Cancer Institute. Gas Cylinder. NCI Thesaurus. Code C43189.

A container designed specifically to hold gases. 